\title{
Compressibility of soils containing kaolinite in acidic environments
}

\author{
Ivan Gratchev ${ }^{1)}$ and Ikuo Towhata ${ }^{2)}$
}

1) Senior Lecturer, Griffith School of Engineering, Griffith University, Australia.Email: ivangratchev@gmail.com

2) Professor, Department of Civil Engineering, The University of Tokyo, Japan.

\begin{abstract}
.
This paper seeks to understand the effect of acidic fluids on the compressibility of soil. Three natural soils (namely, Kansai clay, Yurakucho silt, and Oumigawa silt) containing kaolinite were leached with solutions of sulphuric acid for various lengths of time. At the end of each time interval, standard compression (oedometer) tests were performed to study the behavior of soil in an acidic environment. It was found that the soil structure had a significant effect on the compressibility of clay at low pH. For the Kansai clay and Yurakucho silt, the undisturbed specimens yielded greater compression indices as $\mathrm{pH}$ values decreased. In addition, the data indicated that for all three soils, a decrease in $\mathrm{pH}$ correlated with an increase in the compression index. Based on the obtained results and available literature, the mechanisms controlling the compressibility of the studied soils at low $\mathrm{pH}$ values were discussed.
\end{abstract}


KEY WORDS: acid; contamination; clay; compressibility; clay mineralogy; soil structure.

\section{INTRODUCTION}

It has been long recognized that changes in pore water chemistry have a significant influence on the compressibility of soil, which in turn can affect the stability of engineering structures built on such soils (Sridharan et al. 1981, and Rao and Rao 1994). A number of studies, including Bolt (1956), Rosenqvist (1959), Olson and Mesri (1970), Sridharan and Rao (1973), Meegoda and Ratnaweera (1994), Chen et al. (2000), Wang and Siu (2006), Sunil et al. (2006), and Gajo and Maines (2007), have been performed in the past few decades to better understand the effect of chemicals in the pore fluid on the compressibility of soil. This research has provided useful insights into the roles of the dielectric constant and inorganic solutions in the behavior of clays under different stresses. However, only little has been done regarding the effect of acidic fluids on the compressibility of soil despite the growing rate of acidic contamination in developed areas. For example, Kamon et al. (1997) reported that the $\mathrm{pH}$ of rain water decreased to approximately 4.0 due to the presence of sulfates $\left(\mathrm{SO}_{4}{ }^{2-}\right)$, and suggested that this change would affect the engineering properties of soil. It is noted that chemical weathering of natural rocks can also result in the formation of acidic groundwater, which, in turn, would affect the properties of soil (Chigira and Yagi 2005, Gratchev and Towhata 2010).

Another issue that requires clarification is the duration of contamination and its effect on soil structure. Sridharan et al. (1981) reported that the process of soil contamination in 
the field can take from several months to a few years, while Oztoprak and Pisirici (2011) noted that even after 15-30 day of soil exposure to contamination (landfill leachate), the soil structure can undergo significant transformation which may cause changes in soil compressibility. However, due to time constraints, the majority of laboratory studies have elected to reproduce the process of contamination over the span of a few days by mixing remoulded soil samples with different pore fluids. Although this approach has yielded satisfactory results, it neglects the effects of soil structure and limits our understanding of the processes that lead to changes in soil compressibility.

This study seeks to shed light on these issues by providing laboratory data regarding the compressibility of natural soils subjected to long-term acidic contamination. The behavior of undisturbed and remoulded samples prepared at the same $\mathrm{pH}$ values was compared to determine the effect of soil structure on the consolidation properties of soils. On the basis of the obtained data and available literature, the mechanisms controlling the compressibility of soils containing kaolinite were posited. This paper presents and discusses the obtained results.

\section{REVIEW OF THE PREVIOUS WORKS}

In recent years, some research has been conducted to understand the influence of $\mathrm{pH}$ conditions on soil plasticity (Kamon et al. 1997), strength (Gajo and Maines 2007, Wang and Siu 2006, Gratchev and Sassa 2013, Gratchev and Towhata 2013), hydraulic conductivity (D’Appolonia 1980, Kashir and Yanful 2001) and compressibility (Imai et al. 2006, Gratchev and Towhata 2011a). These studies indicated that several processes could occur due to soil-water-acid interaction, including 1) the dissolution of chemical 
compounds or organic matter, 2) changes in the thickness of the diffuse double layer, and 3) formation of the $\mathrm{pH}$-dependent charges on the edges of clay particles. It is noted that these processes are common for the $\mathrm{pH}$ range of 3-6, which is typically encountered in engineering practice. Mitchell (1993) noted that at extremely high concentrations of acid $(\mathrm{pH} \approx 1)$, changes in the mineral structure can also occur which may affect the properties of clay, including its compressibility.

- It has been recognized that acid can dissolve cementation agents such as calcium carbonates and ferric oxides (Mitchell 1993) altering the structure of natural clays. Imai et al. (2006) leached clay containing calcium carbonates with solutions of hydrogen chloride to dissolve the carbonate minerals between clay particles/aggregates and reported that the consolidation yield stress of the clay decreased in proportion to the decrease of the calcium carbonate content. Gratchev and Towhata (2009) studied the compressibility of Ariake clay from Japan leached with acidic fluids and noted that the compressibility of soil increased mostly due to the dissolution of ferric oxides between clay aggregates. Man and Graham (2010) investigated the effect of pore fluid chemistry on the behavior of highly plastic clay cemented by gypsum and pointed out that removal of the gypsum cementation reduced the strength of soil.

- High concentrations of acid in the pore water also affect the thickness of the diffuse double layer of clay particles (Van Olphen 1991). As the pH of pore fluids drops from neutral $(\mathrm{pH} \approx 7.0)$ to acidic, $\mathrm{H}^{+}$-ions would replace the commonly found exchanged cations in the clay, resulting in an increase in the double-layer thickness (Gajo and Maines 2007). However, as the amount of $\mathrm{H}^{+}$-ions in the pore fluid still increases (that is, the $\mathrm{pH}$ becomes more acidic), the thickness of the diffused double layer is expected to 
decrease (Van Olphen 1991). At some point, the amount of $\mathrm{H}^{+}$-ions in the pore fluid will eventually reach the concentration at which the diffuse double layer will collapse (Mitchell 1993), a process that will affect the compressibility of soil. For example, Gajo and Maines (2007), who leached bentonite with acidic fluids, reported that the compressibility of bentonite decreased significantly due to the collapse of the diffuse double layer at low $\mathrm{pH}$.

- It is well-known from colloid chemistry (Van Olphen 1991) that in acidic medium, the charge on the edges of clay particles will become increasingly positive due to the adsorption of $\mathrm{H}^{+}$-ions, resulting in flocculated, face-to-edge (F-E) structures (Dolinar and Trauner 2007). Although this mechanism can occur in soils with different clay mineralogy, it appears to have the most influence on kaolinitic soils due to the size and structure of kaolinite particles (Mitchell 1993, Ma and Eggleton 1999). Results of laboratory tests conducted on kaolinitic soils indicate that clays with open-flocculated structures exhibit greater permeability (Mitchell 1993, Sridharan and Prakash 1999) and higher liquid limits (Sridharan et al. 1988, Gratchev and Sassa 2009). The formation of open-flocculated structures is expected to affect the compressibility of clay as well, increasing the soil capacity to compress under load application. This hypothesis will be tested in this study.

From the above review, it can be inferred that there are several major mechanisms that can significantly alter the compressibility of soil under low $\mathrm{pH}$ conditions. Furthermore, the effect of each mechanism greatly depends on the clay mineralogy, soil structure, and the $\mathrm{pH}$ of pore fluid. As some of the processes can occur simultaneously and have opposite effects on the properties of clay, the prediction of soil behavior at low $\mathrm{pH}$ values 
becomes a rather difficult task. This study seeks to better understand the behavior of three natural soils containing kaolinite at low $\mathrm{pH}$ values.

\section{SOILS TESTED AND LIQUIDS USED}

Three soils from Japan, namely Kansai clay, Yurakucho silt, and Oumigawa silt, were tested in this work. The grain size distribution curves of these soils are given in Fig. 1.

Borehole samples of the Kansai clay from the Osaka Bay near the Kansai International Airport were kindly provided by the Port and Airport Research Institute (PARI), Japan. The soil samples had a liquid limit (LL) of 66.4, and a plasticity index (PI) of 34.8. X-ray analysis conducted by the Analysis Center Co., Ltd., Japan, revealed such minerals as kaolinite, smectite, chlorite, illite, and calcite.

Undisturbed samples of Yurakucho silt were collected from a construction site in the northern part of Tokyo in blocks (cubic shape with $50 \mathrm{~cm}$ in size). The results of Atterberg limits tests conducted on specimens with distilled water indicated that the soil had $\mathrm{LL}=50.9$ and $\mathrm{PI}=15.8$. The fines content $(<0.074 \mathrm{~mm})$ was found to be $42 \%$, and the clay fraction $(<0.002 \mathrm{~mm}$ ) was approximately $17 \%$ (Fig. 1$)$. The X-ray analysis revealed the presence of kaolinite and chlorite.

The Oumigawa silt ( $\mathrm{LL}=47.2, \mathrm{PI}=8.4$ ) was obtained from the sliding zone of the Oumigawa landslide that occurred in Niigata Prefecture during the 2007 Chuetsu Oki earthquake (Gratchev and Towhata 2011b). Kaolinite and chlorite were found to be the main clay minerals.

It is noted that kaolinite was found to be the dominant clay mineral in the Yurakucho and Oumigawa silt. For the Kansai clay, it was rather difficult to determine the dominant 
clay mineral as smectite and calcite seem to have contributed to soil behavior as well.

To study the effect of acidic fluids that can be resulted from acid rain or acidic ground water, sulphuric acid $\left(\mathrm{H}_{2} \mathrm{SO}_{4}\right)$ was diluted with distilled water to produce acidic liquids with $\mathrm{pH} \approx 4.0$. This liquid was used to leach soil samples, thus simulating the process of $\mathrm{pH}$ contamination. All $\mathrm{pH}$ measurements were performed by a $\mathrm{pH}$ meter (accuracy \pm 0.01 ).

\section{EXPERIMENTAL PROCEDURE}

\section{Containers for leaching of soil specimens}

To reproduce the process of soil-water-chemicals interaction in the laboratory, a special container (height $=25 \mathrm{~cm}$, length $=30 \mathrm{~cm}$, and width $=12 \mathrm{~cm}$ ) as schematically shown in Fig. 2 was utilized. The soil sample (height of $2.2 \mathrm{~cm}$ ) was sandwiched between two flat perforated PVC plates of $5 \mathrm{~mm}$ thickness with circular holes of diameter $6 \mathrm{~mm}$ at $6 \mathrm{~mm}$ spacing. Filter paper was placed in between the soil specimen and the plates to prevent loss of the soil. The specimen was kept confined under the pressure of $10 \mathrm{kPa}$ to ensure the same stress conditions during leaching. PVC pipes were used as supporting columns as shown in Fig. 2, providing an open area for acidic liquid. Several containers were simultaneously used to leach the soil with acidic fluids. The amount of soil sample in each container was sufficient to perform 3 compression tests.

\section{Specimen preparation and test procedure}

To study the effect of soil structure on the compressibility of soil leached with acidic liquids, undisturbed and remoulded samples of Kansai clay and Yurakucho silt were utilized. Borehole samples of Kansai clay with a diameter of $10 \mathrm{~cm}$ were first cut into 
specimens with a height of approximately $2.2 \mathrm{~cm}$ and placed in the container. The Yurakucho silt samples were cut out of the undisturbed blocks to form specimens with a height of about $2.2 \mathrm{~cm}$ as well. $3 \mathrm{~L}$ of the acidic liquid was poured into the container to initiate the interaction between the soil and acidic water. The container was covered with a lid to prevent vaporization of the fluid. In the first few weeks, the measurements of $\mathrm{pH}$ were performed on a daily basis to monitor changes in the $\mathrm{pH}$ of the liquid caused by soil-water-chemicals interaction. It was observed that some changes in the $\mathrm{pH}$ typically occurred in the first 3-4 days before its value became constant after approximately 6-7 days. Based on the acquired experience, it was decided that a 7-day time interval was sufficient for the $\mathrm{pH}$ of pore fluid to stabilize. After 7 days, the liquid (e.g., effluent liquid) was removed (about $2.5 \mathrm{~L}$ ) from the container and its $\mathrm{pH}$ and electrical conductivity were measured and recorded. The container was then re-filled with the original acidic solution (about $2.5 \mathrm{~L}$ ) and this procedure was repeated a number of times to decrease the $\mathrm{pH}$ value of the effluent liquid.

The $\mathrm{pH}$ and electrical conductivity of effluent liquid obtained during leaching for all three soils are summarized in Fig. 3. It is evident from this figure that significant time was required to prepare soil samples with low $\mathrm{pH}$ values. For example, about 100 days were necessary (Fig. 3a) to produce a sample of Kansai clay with the $\mathrm{pH}$ of effluent liquid of 6.92, while as many as 250 days were required for a sample of the same soil but with a lower $\mathrm{pH}$ of 6.01 . It is clear from Fig. 3b that the electrical conductivity (EC) gradually decreased during leaching, suggesting that the concentration of dissolved ions in the effluent liquid also decreased. Relatively high values of EC obtained for the Kansai clay can be attributed to the dissolution of calcite during acid-water-soil interaction. 
After decreasing the $\mathrm{pH}$ of effluent liquid by about 0.5 units, some soil was retrieved from the container. To study the effect of soil structure for Kansai clay and Yurakucho silt, a half of the retrieved soil was used to perform compression tests (referred to as "undisturbed"), while the other half was remoulded to produce uniform slurry ("remoulded" samples). This slurry was then pre-consolidated to an effective vertical stress of $10 \mathrm{kPa}$ in a one-dimensional consolidometer (with a diameter of $6 \mathrm{~cm}$ ) until at least $90 \%$ of consolidation was achieved. This consolidated slurry was trimmed to a standard size of 6-cm diameter, and 2-cm height, and tested in an odometer.

For the Oumigawa silt, the same procedure as described above was utilized to prepare specimens for oedometer tests. However, the original structure of the samples was already remoulded during the soil collection and storage, and thus the results of compression tests were mostly analysed to better understand the effect of acidic environments on the compressibility of kaolinitic soils.

All compression tests were performed, according to the Japanese Test Standard (JIS A 1217). Overburden stress was applied in increments of 9.8, 19.6, 39.2, 78.5, 157, 314, 628, and $1256 \mathrm{kPa}$, followed by unloading. The oedometer was covered with a polythene wrap during soil consolidation to minimize chemical vaporization of pore fluids. The compression index $\mathrm{C}_{\mathrm{c}}$, or the slope of the virgin compression curve, was computed as follows: $\mathrm{C}_{\mathrm{c}}=\left(\mathrm{e}_{157 \mathrm{kPa}}-\mathrm{e}_{1256 \mathrm{kPa}}\right) /(\log (1256 \mathrm{kPa} / 157 \mathrm{kPa}))$.

\section{TEST RESULTS}

\section{Kansai clay}

Results from compression tests on the undisturbed (a) and remoulded (b) specimens of 
Kansai clay under different $\mathrm{pH}$ conditions are presented in Fig. 4. It is evident from this figure that for both undisturbed and remoulded samples, the specimens with lower $\mathrm{pH}$ values have greater initial void ratios, which may be the result of their longer exposure to leaching. To have a better understanding of the effect of $\mathrm{pH}$ on the compression characteristics of Kansai clay, the obtained results are re-plotted in Fig. 5a in terms of the compression index $\left(\mathrm{C}_{\mathrm{c}}\right)$ vs. $\mathrm{pH}$. For the undisturbed specimens, it can be stated that 1$)$ the compression indices of clay specimens with $\mathrm{pH}$ values in the range of 6.65 to 7.09 are very similar to the one that was obtained for the specimen with distilled water $\left(\mathrm{C}_{\mathrm{c}}=0.474\right)$, and 2) at the lower $\mathrm{pH}$ values, the compression index greatly increased to $0.722 \sim 0.756$. It is noted that the liquid limit (LL) and plasticity index (PI) of the Kansai clay also increased as the $\mathrm{pH}$ of the effluent liquid decreased (Fig. 5b).

Compared to the undisturbed samples, the remoulded specimens of Kansai clay yielded lower values of compression indices over the whole range of $\mathrm{pH}$ conditions. Also, similar to the undisturbed samples, the compression indices of the remoulded specimens tended to increase when the $\mathrm{pH}$ conditions became more acidic. Figure 6 presents the coefficients of consolidation obtained for the undisturbed and remoulded specimens using the Casagrande method (Casagrande and Fadum 1940). The results indicate that the coefficient of consolidation of the remoulded specimens is greater, resulting in higher rates of consolidation in these samples regardless of the $\mathrm{pH}$ (Fig. 6a,b) and overburden pressure (Fig. 6c,d). 


\section{Yurakucho silt}

Results of compression tests on the Yurakucho silt are given in Fig. 7 for undisturbed (Fig. 7a) and remoulded (Fig. 7b) specimens. In addition, comparisons between the compression indices of the undisturbed and remoulded samples are presented in Fig. 8a. Similar to the Kansai clay, an increase in the compression index was observed for both undisturbed and remoulded samples when the $\mathrm{pH}$ became more acidic. Also, the compression indices of undisturbed specimens were greater than those of the remoulded ones.

Results from the Atterberg limits tests are plotted in Fig. 8b in terms of liquid limit (LL) and plasticity index (PI) against $\mathrm{pH}$. It is evident from these data that both LL and PI tended to increase as the $\mathrm{pH}$ decreased.

\section{Oumigawa silt}

The results from oedometer tests on the Oumigawa silt are presented in Fig. 9a while changes in the compression index against $\mathrm{pH}$ are given in Fig. 9b. It is clear from this figure that an increase in the compression index occurred when the $\mathrm{pH}$ of pore fluid dropped below 5 .

The results of Atterberg limits tests are summarized in Fig. 9c, showing a similar tendency to the one that was observed for the Kansai clay and Yurakucho silt; that is, LL and PI tend to increase as the $\mathrm{pH}$ decreases.

\section{DISCUSSION}

The obtained results indicate that a decrease in $\mathrm{pH}$ correlates with increases in 1) 
compression indices, and 2) LL and PI for all studied soils. It was also observed that the undisturbed specimens of the Kansai clay and Yurakucho silt were more compressible than the remoulded ones.

The effect of soil structure on the compressibility of Kansai clay leached with acidic liquids appears to be more pronounced than that observed for the Yurakucho silt. In particular, the difference in the compression indices of the undisturbed and remoulded specimens of the Kansai clay significantly increased as the pH decreased (Fig. 5a). For example, compared to the sample in distilled water, the compression index of the remoulded samples at $\mathrm{pH}=5.93$ increased by $25 \%$ while for the undisturbed samples, the increase was more than 50\%. In contrast, for the Yurakucho silt, the difference in compression indices of the undisturbed and remoulded samples was almost negligible (Fig. 8a). Such a great effect of acidic fluids on the compressibility of Kansai clay can be attributed to the mineral composition of this soil, especially the presence of calcium carbonate. Similar to Imai et al. (2006), it can be hypothesised that acidic fluids would destroy the carbonate bonds between clay particles/aggregates, forming "loose” structures with larger voids and thus greater compressibility. However, when the samples were remoulded, such "loose" structures were likely to have been destroyed to some degree, and for this reason, the effect of acidic fluids on the compressibility of remoulded samples of the Kansai clay was much smaller. The formation of loose structures during leaching can be seen in higher initial void ratios of the samples with a lower $\mathrm{pH}$.

The similarities in soil behavior observed for the Yurakucho silt and Oumigawa silt can be attributed to their similar mineral composition. As the Yurakucho silt and Oumigawa silt contain kaolinite as the dominant clay mineral, the mechanism that 
occurred during leaching can be related to the $\mathrm{pH}$-dependent charge on the kaolinite edges (Mitchell 1993). Van Olphen (1991) noted that when $\mathrm{pH}<5.5$, the charge on the edges of kaolinite particles becomes increasingly positive, a process that leads to the formation of more open, flocculated structures. The existence of such structures was experimentally verified by Wang and Siu (2006) and Dolinar and Trauner (2007), who studied clay microfabrics of kaolinite by means of scanning electron microscope. Thus it is logical to assume that such open clay microfabrics would be more compressible, producing soil structures with higher compression indices. It is noted that a significant increase in the compression index of both Yurakucho silt (Fig. 8a) and Oumigawa silt (Fig. 9b) occurred only after the $\mathrm{pH}$ of pore fluid dropped below 5.5 .

Results of Atterberg limits tests performed on the Yurakucho and Oumigawa silt (Figs. 8b and 9c) at different $\mathrm{pH}$ values provide more support for the above-mentioned hypothesis. According to Sridharan et al. (1988), more open flocculated arrangements of kaolinite particles al low pH should enclose large spaces for water entrapment and thus produce greater liquid limits. The data given in Figs. 8b and 9c show that the liquid limit of Yurakucho and Oumigawa silt did indeed increase at low $\mathrm{pH}$ after the soil was leached with acidic fluids.

The available literature suggests that the effect of diffuse double layer on the compressibility of soil is the most pronounced for clays containing smectite/montmorillonite (Mitchell 1993) and almost negligible for kaolinitic soils such as the Yurakucho and Oumigawa silt. For the Kansai clay, which also contains smectite, changes in the diffuse double layer can occur simultaneously with the dissolution of calcite and the formation of more open, flocculated kaolinite structures, which makes it 
rather difficult to single out the dominant process.

\section{CONCLUSIONS}

In this work, changes in the compressibility of three natural soils subjected to longterm acidic leaching were studied. Based on the obtained results, the following conclusions can be drawn:

- For the Kansai clay and Yurakucho silt, undisturbed soil specimens were more compressible than the remoulded samples under same $\mathrm{pH}$ conditions.

- The greatest increase in the compressibility was observed for the Kansai clay when the compression index of the undisturbed samples increased by $50 \%$. This may be attributed to the presence of calcium carbonates that can be dissolved by acidic liquids.

- For the Yurakucho and Oumigawa silt, a decrease in the $\mathrm{pH}$ of pore water correlated with an increase in the compression index. The largest increase in the compression index was observed when the $\mathrm{pH}$ of pore water became less than 5.5 .

\section{ACKNOWLEDGEMENTS}

The clay samples used in this research were kindly provided by the Port and Airport Research Institute, Japan. X-ray analysis was performed by Analysis Center Co., Ltd., Japan. Financial support was provided by the Japan Society for the Promotion of Science (JSPS). 


\section{REFERENCES}

Bolt, G. (1956). "Physicochemical analysis of the compressibility of pure clays." Géotechnique, Vol. 6, No. 2, pp. 86-93, DOI: 10.1680/geot.1956.6.2.86.

Casagrande, A., and Fadum, R. (1940). "Notes on soil testing for engineering purposes.”, Harvard University Graduate School for Engineering publication No. 8.

Chen, J., Anandarajah, A., and Inyang, H. (2000). "Pore fluid properties and compressibility of kaolinite.” Journal of Geotechnical and Geoenvironmental Engineering ASCE, Vol. 126, No. 9, pp. 798-807, DOI: http://dx.doi.org/10.1061/(ASCE)1090-0241(2000)126:9(798)).

Chigira, M., and Yagi, H. (2005). Geological and geomorphological characteristics of landslides triggered by the 2004 Mid Niigata prefecture earthquake in Japan. Engineering Geology 82, 202-221.

D’Appolonia D (1980) Soil-bentonite slurry trench cutoffs. Journal of Geotechnical and Geoenvironmental Engineering ASCE 106 (4), 399-417

Dolinar, B., and Trauner, L. (2007). "The impact of structure on the undrained shear strength of cohesive soils.” Engineering Geology, Vol. 92, pp. 88-96, http://dx.doi.org/10.1016/j.enggeo.2007.04.003.

Gajo, A., and Maines, M. (2007). "Mechanical effects of aqueous solutions of inorganic acids and bases on a natural active clay.” Géotechnique, Vol. 57, No. 8, pp. 687-699, DOI: 10.1680/geot.2007.57.8.687. 
Gratchev, I., and Sassa, K. (2009). "Cyclic behavior of fine-grained soils at different pH values.” Journal of Geotechnical and Geoenvironmental Engineering ASCE, Vol. 135, No. 2, pp. 271-279, http://dx.doi.org/10.1061/(ASCE)1090-0241(2009)135:2(271).

Gratchev, I., and Towhata, I. (2009). "Effects of Acidic Contamination on the Geotechnical Properties of Marine Soils in Japan.” Proc., ISOPE-2009 Osaka: 19th (2009) International Offshore (Ocean) and Polar Engineering Conference, pp. 151-155.

Gratchev I., and Towhata, I. (2010). "Geotechnical characteristics of volcanic soil from seismically-induced Aratozawa landslide, Japan.” Landslides 7, 503-510.

$10.1007 / \mathrm{s} 10346-010-0211-2$

Gratchev, I., and Towhata, I. (2011a). “Compressibility of natural soils subjected to longterm acidic contamination.” Environmental Earth Sciences, Vol. 64, pp. 193-200, DOI: 10.1007/s12665-010-0838-2.

Gratchev, I., and Towhata, I. (2011b). “Analysis of the mechanisms of slope failures triggered by the 2007 Chuetsu Oki earthquake.” Geotechnical and Geological Engineering, Vol. 29, No. 5, pp. 695-708, DOI: 10.1007/s10706-011-9411-3.

Gratchev, I., and Sassa, K. (2013). “Cyclic Shear Strength of Soil with Different Pore Fluids.” Journal of Geotechnical and Geoenvironmental Engineering ASCE, Vol. 139, No. 10, pp. 1817-1821. http://dx.doi.org/10.1061/(ASCE)GT.1943-5606.0000901.

Gratchev, I., and Towhata, I. (2013). "Stress-strain characteristics of two natural soils subjected to long-term acidic contamination.” Soils and Foundations 53 (3): 469-476, http://dx.doi.org/10.1016/j.sandf.2013.04.008.

Imai, G., Komatsu, Y., Fukue, M. (2006). "Consolidation Yield Stress of Osaka-Bay Pleistocene Clay with Reference to Calcium Carbonate Contents.” J ASTM International, 
Vol. 3, pp. 1-9, DOI: 10.1520/JAI13325.

Japanese Standard Procedure for One-dimensional Consolidation Test JIS A 1217

Kamon, M., Ying, C., and Katsumi, T. (1997). "Effect of acid rain on physico-chemical and engineering properties of soils.” Soil and Foundations, Vol. 37, No. 4, pp. 23-32.

Kashir, M., and Yanful, E. (2001). "Hydraulic conductivity of bentonite permeated with acid mine drainage.” Canadian Geotechnical Journal, Vol. 38, pp. 1034-1048, DOI: 10.1139/t01-027.

Ma, C., and Eggleton, R. (1999). “Cation exchange capacity of kaolinite.” Clay and Clay Minerals, Vol. 47, No. 2, pp. 174-180.

Man, A., and Graham, J. (2010). "Pore fluid chemistry, stress-strain behaviour, and yielding in reconstituted highly plastic clay.” Engineering Geology, Vol. 116, pp. 296310, http://dx.doi.org/10.1016/j.enggeo.2010.09.011

Meegoda, N., and Ratnaweera, P. (1994). “Compressibility of contaminated fine-grained soils.” Geotechnical Testing Journal, Vol. 17, No. 1, pp. 101-112, DOI: 10.1520/GTJ10078J.

Mitchell, J. (1993). Fundamentals of soil behavior. John Wiley \& Sons.

Olson, R.E., and Mesri, G. (1970). "Mechanism controlling compressibility of clays.” Journal of the SMFE Division ASCE, Vol. 6, No. 11, pp. 1863-1878.

Oztoprak, S., and Pisirici, B. (2011). "Effect of micro structure changes on the macro behaviour of Istanbul (Turkey) clays exposed to landfill leachate.” Engineering Geology, Vol. 121, pp. 110-122, http://dx.doi.org/10.1016/j.enggeo.2011.05.005.

Rao SM, Rao SS (1994) Ground heave from caustic soda solution spillage- a case study. Soils and Foundations 34 (2): 13-18 
Rosenqvist I (1959) Physico-Chemical properties of Soils: Soil Water Systems. Journal of the SMFE Division ASCE 85 (2): 31-53

Sridharan, A., and Rao, G.V. (1973). "Mechanisms controlling volume change of saturated clays.” Geotechnique, Vol. 23, No. 3, pp. 359-382, DOI: 10.1680/geot.1973.23.3.359.

Sridharan A, Nagaraj T, Sivapullaiah P (1981) Heaving of soil due to acid contamination. Proc. $10^{\text {th }}$ International Conference on Soil Mechanics and Foundation Engineering, Stockholm: 383-386

Sridharan, A., Rao, S.M., and Murthy, N.S. (1988). "Liquid limit of kaolinitic soils.” Geotechnique, Vol. 38, No. 2, pp. 191-198, DOI: 10.1680/geot.1988.38.2.191.

Sridharan, A., and Prakash, K. (1999). "Mechanisms controlling the undrained shear strength behaviour of clays.” Canadian Geotechnical Journal, Vol. 36, pp. 1030-1038, DOI: $10.1139 / \mathrm{t} 99-071$.

Sunil, B.M., Nayak, S., and Shriharj, S. (2006). "Effect of pH on the geotechnical properties of laterite.” Engineering Geology, Vol. 85, No. 1-2, pp. 197-203, http://dx.doi.org/10.1016/j.enggeo.2005.09.039.

Van Olphen, H. (1991). An introduction to clay colloid chemistry. Krieger Publishing Company.

Wang, Y., and Siu, W. (2006). "Structure characteristics and mechanical properties of kaolinite soils. 1. Effects of structure on mechanical properties." Canadian Geotechnical Journal, Vol. 43, pp. 587-600, DOI: 10.1139/t06-026. 


\section{FIGURE CAPTIONS}

Figure 1. Grain size distribution curves of the studies soils.

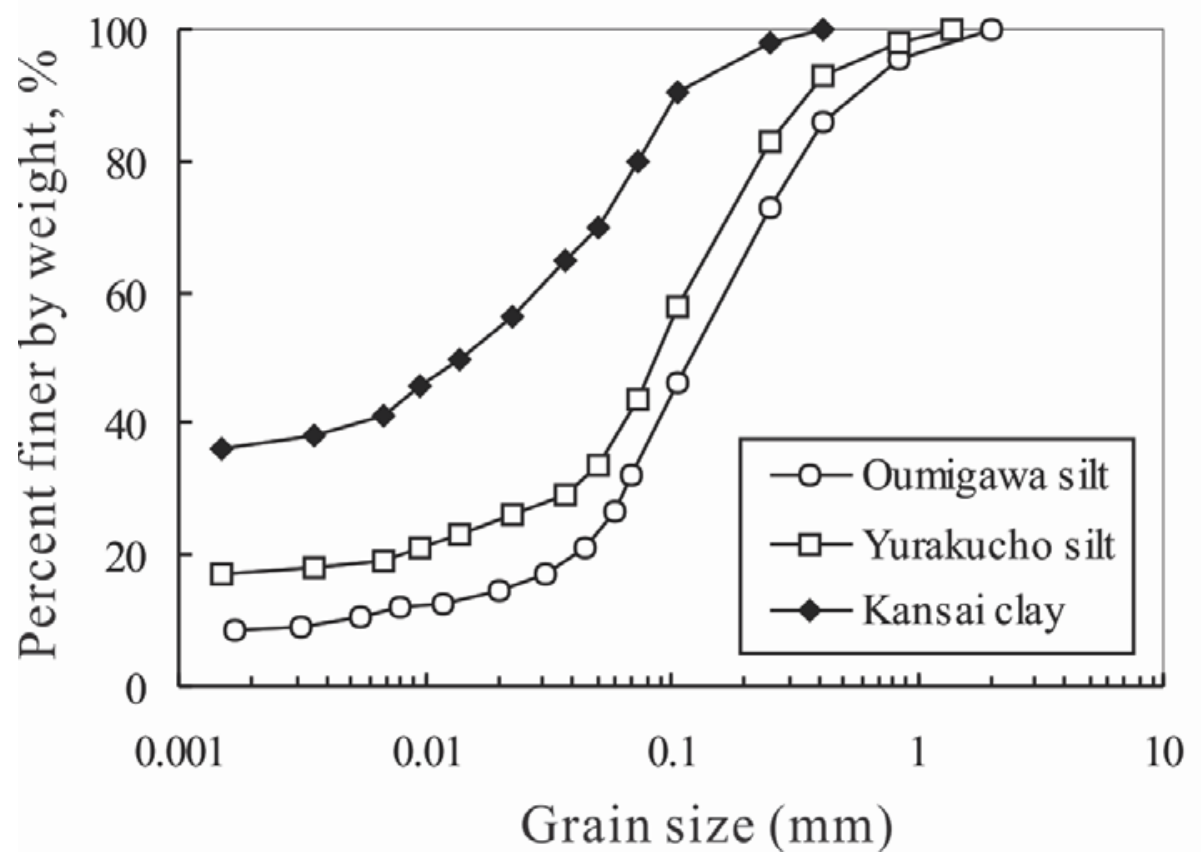

Figure 2. A schematic setup of a container used to leach soil with acidic fluids.

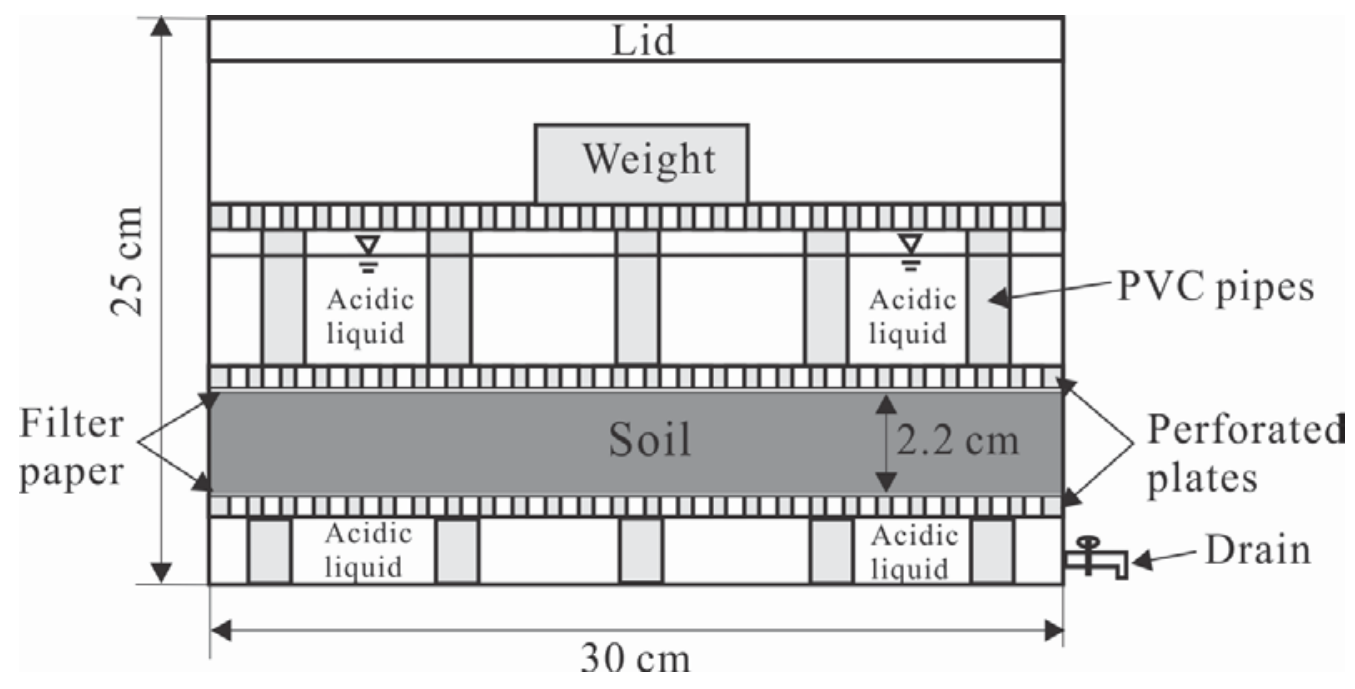


Figure 3. Results of leaching tests plotted as a) time vs. changes in $\mathrm{pH}$, and b) time vs. electrical conductivity.
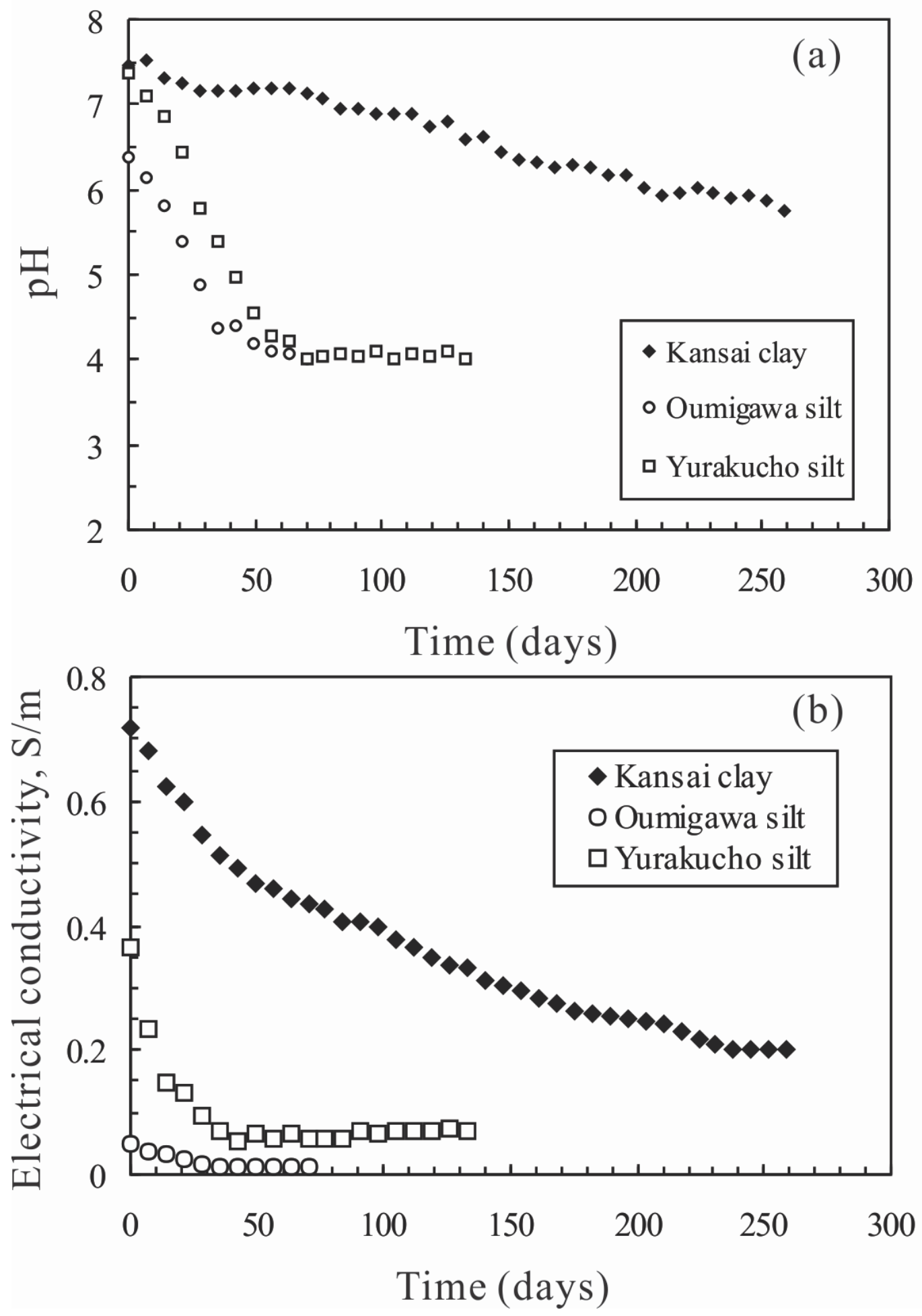
Figure 4. Results of compression tests on the Kansai clay: compression curves obtained for undisturbed (a) and remoulded (b) specimens.
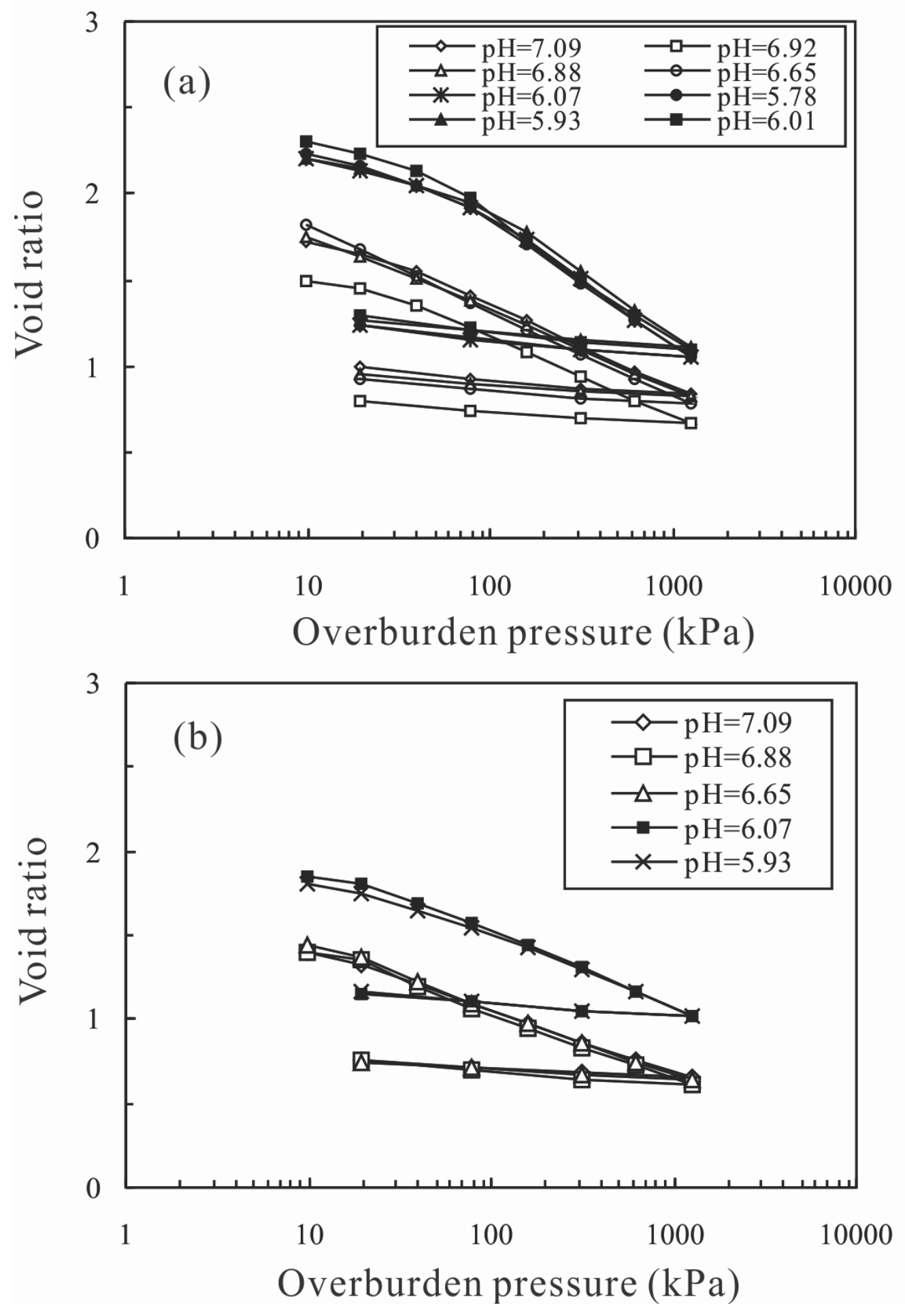
Figure 5. Variation of the compression index (a) and Atterberg limits (b) of the Kansai clay with $\mathrm{pH}$.
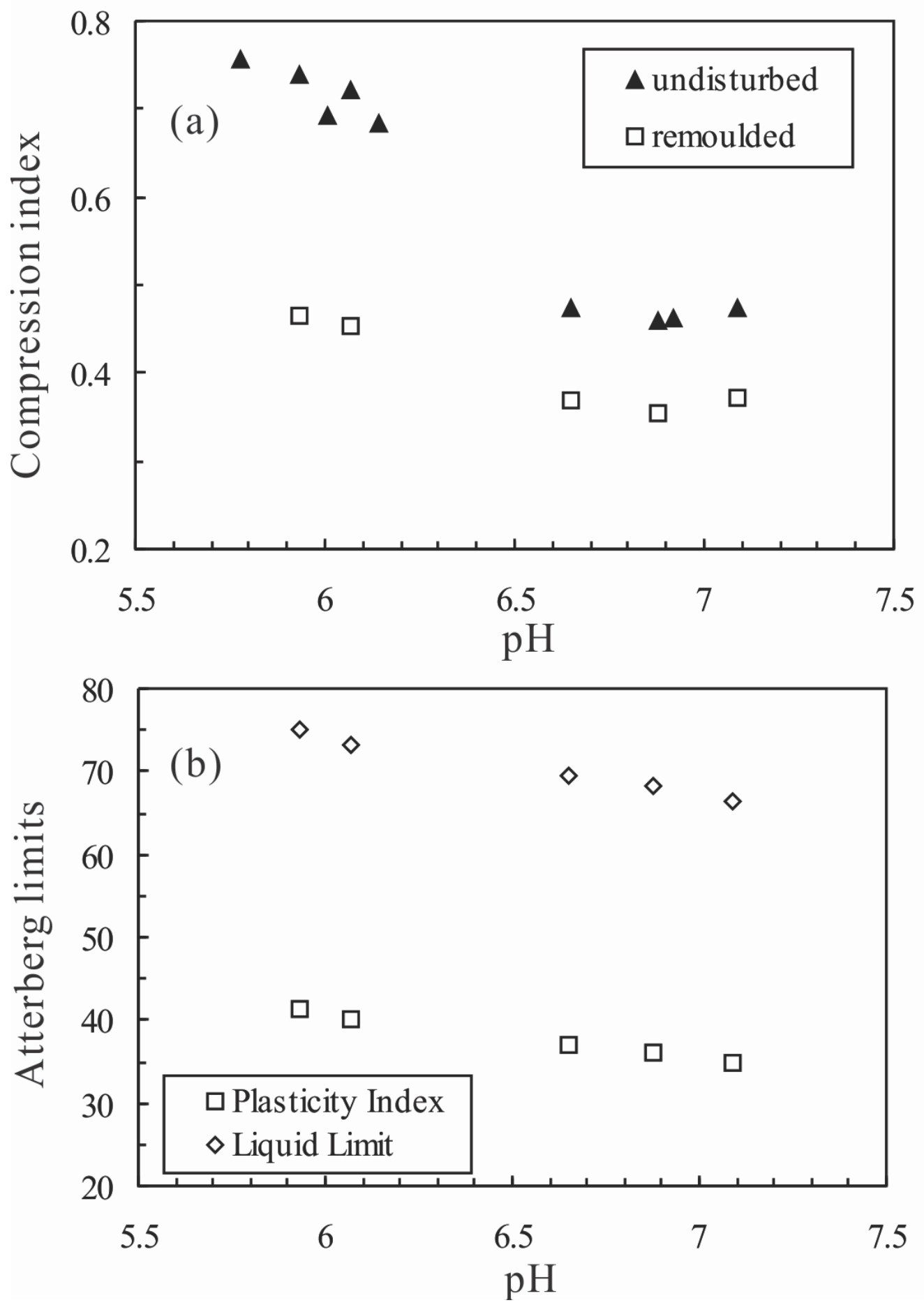
Figure 6. Variation of the coefficient of consolidation of the Kansai clay with overburden pressure and $\mathrm{pH}$.
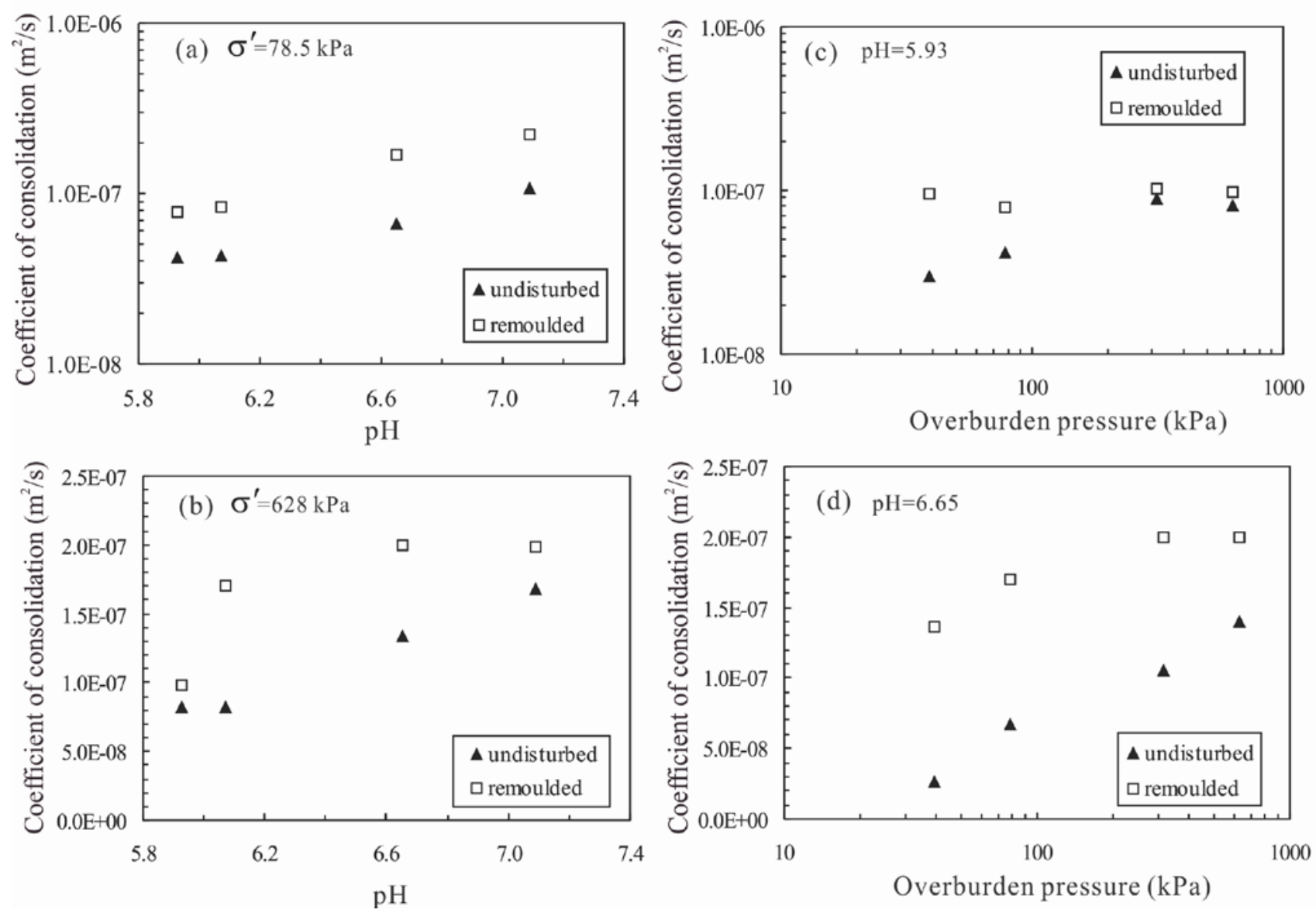
Figure 7. Results of compression tests on the Yurakucho silt: compression curves obtained for undisturbed (a) and remoulded (b) specimens.
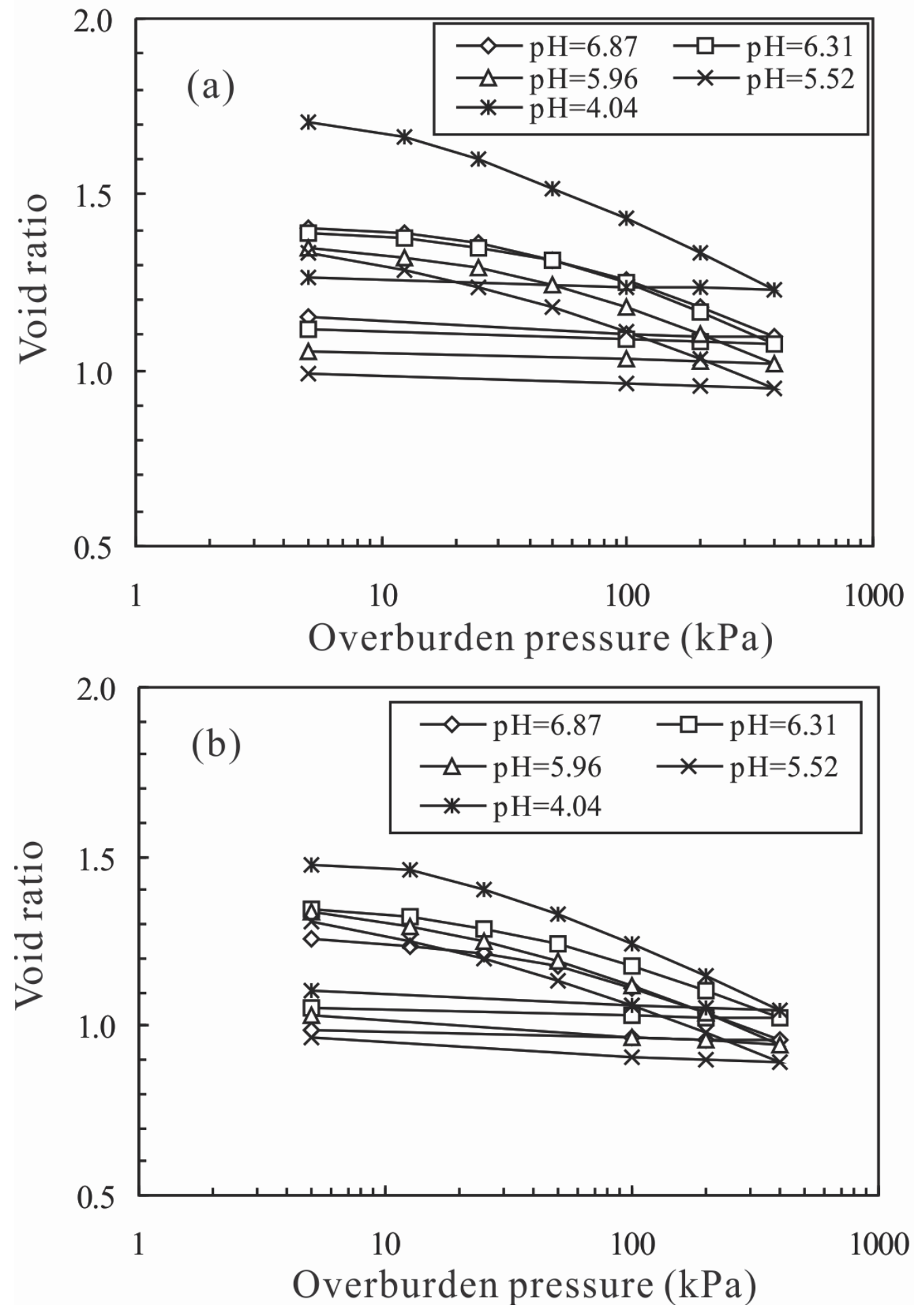
Figure 8. Variation of the compression index (a) and Atterberg limits (b) of the Yurakucho silt with $\mathrm{pH}$.
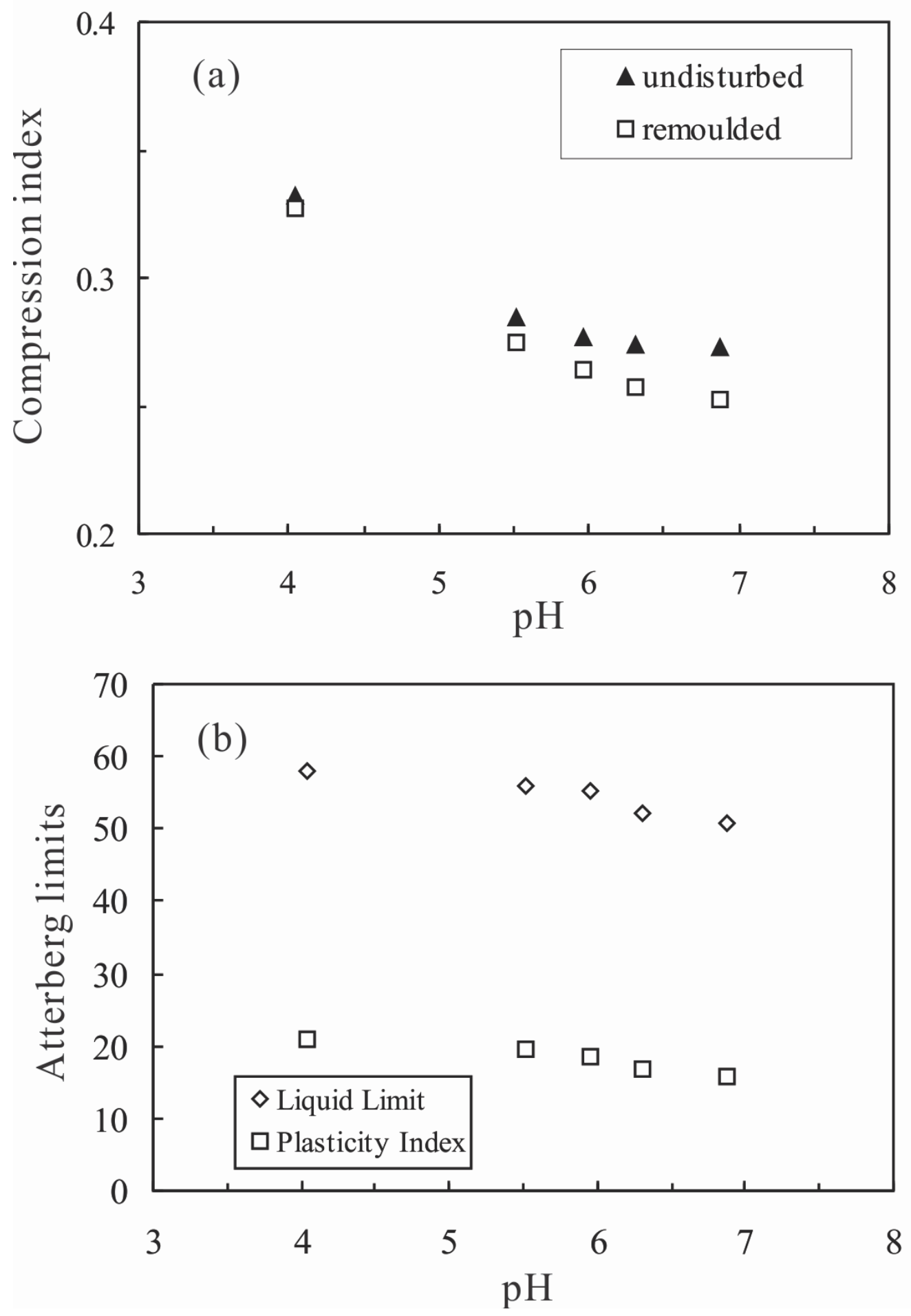
Figure 9. Results of compression tests on the Oumigawa silt: a) compression curves; and b) compression index against $\mathrm{pH}$. Variation of Atterberg limits with $\mathrm{pH}$ (c).
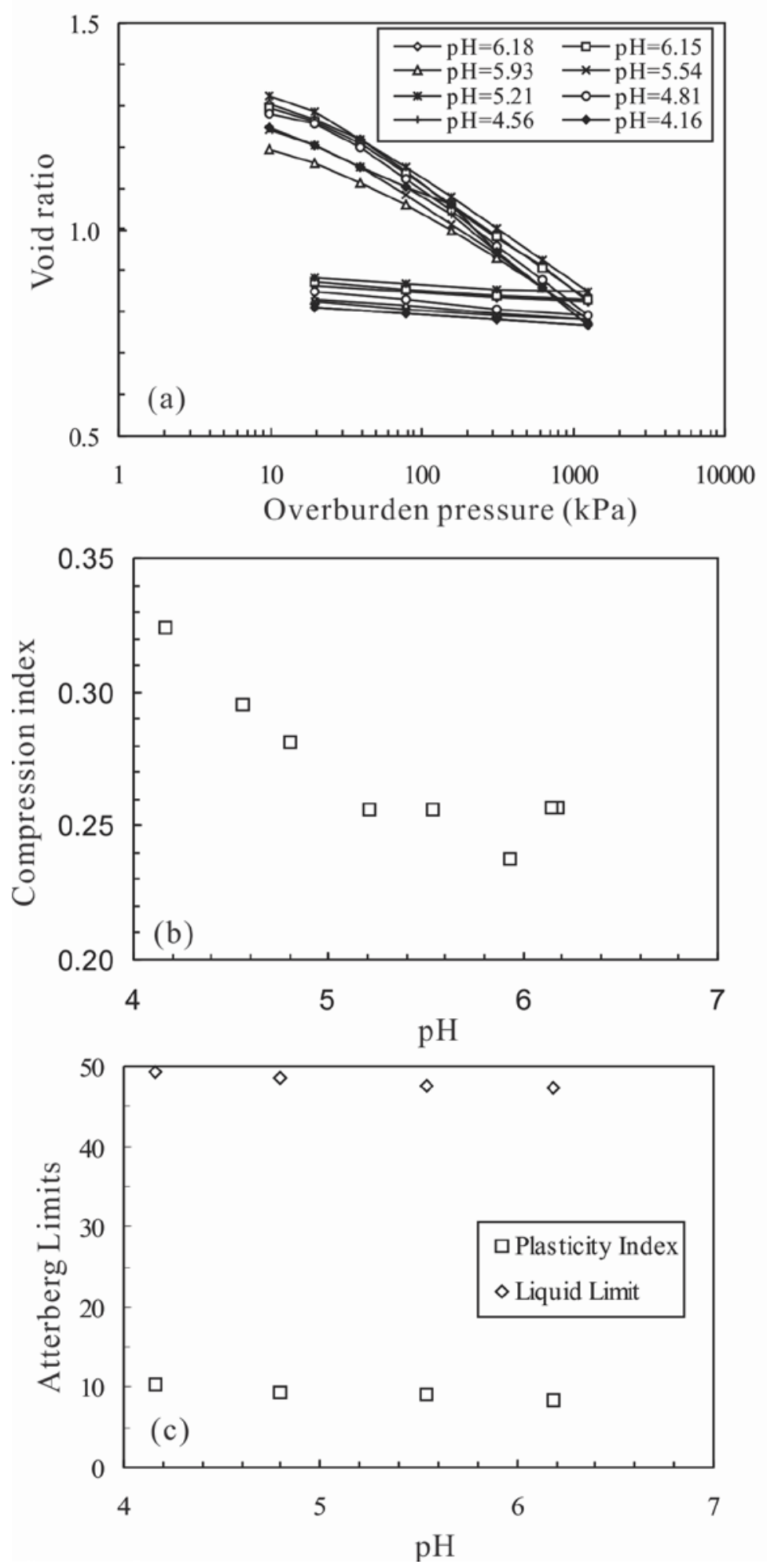